\title{
PROACTIVE DEMAND AND CAPACITY MANAGEMENT FOR AUTOMOTIVE LOGISTICS USING AN EFFICIENT INFORMATION MODEL
}

\author{
Lisanne Temur $^{(\mathrm{a})}$, Daniel Fruhner ${ }^{(\mathrm{b})}$, Katja Klingebiel ${ }^{(\mathrm{c})}$ \\ (a) Volkswagen Nutzfahrzeuge \\ (b) IDiAL Institute, Dortmund University of Applied Sciences and Arts \\ (c) Faculty of Business Studies, Dortmund University of Applied Sciences and Arts \\ (a) lisanne.temur@volkswagen.de, ${ }^{(b)}$ daniel.fruhner@fh-dortmund.de, ${ }^{(c)}$ katja.klingebiel@ @fh-dortmund.de
}

\begin{abstract}
The increasing technical complexity of cars and the high number of offered options lead to new challenges in the automotive industry and especially the mid-term demand and capacity management (DCM). This requires a procedural adaptation based upon an efficient information model. In this contribution, the state of the art is analysed for both the DCM process and the underlying information models. Promising concepts for managing the steadily increasing requirements in DCM are deducted, and a modular process kit for the procedural adaptation combined into the concept SmartDCM is introduced. Additionally, a new approach of an efficient information model for managing the increasingly complex information is presented.
\end{abstract}

Keywords: automotive demand and capacity management, information model

\section{INTRODUCTION}

Technological developments in the automotive industry are increasingly complex (Nagel 2011). They are influenced strongly by continuous derivatisation and an ongoing shortening of the product life cycle (PLC) (Filla and Klingebiel 2014, Hegner 2010, Romberg and Haas 2005). The resulting technical complexity of cars and the decreasing time-to-market lead to a reduced development time (Filla and Klingebiel 2014, Kuhn et al. 2002). Moreover, the possible combinations of different options, which are offered to customers, often account for more than $10^{32}$ available variants of middle-class cars - roughly the same number as atoms in the human body (Meyr 2004). The amount of data to handle all variants is considered unmanageable (Liebler 2013).

Over the past 30 years, automotive suppliers have taken power over the automotive manufacturing process (Wong 2017). The share of value-added by automotive suppliers in global automotive manufacturing has increased from 56\% in 1985 to $85 \%$ in 2015 (Wong 2017). The product complexity, in combination with the reduction in vertical integration, leads to a strong dependence of original equipment manufacturers (OEMs) on their supplier networks (Klug 2010).
Foresighted planning is of central importance in a global and resource-optimised value chain. The critical process is the demand and capacity management (DCM): capacities are aligned with demands to avoid later bottlenecks that cause expensive capacity adjustments or production breakdowns (Askar 2008). DCM has to adapt to the changes in external and internal conditions.

This contribution presents the modular process kit SmartDCM supporting a proactive and event-oriented production program evaluation as a key step in the automotive DCM. The concept is based upon a new information model, which effectively transparently unites all required information.

The paper is structured as follows: all relevant terms and concepts, including the automotive DCM process as well as present challenges, are introduced in section 2 . The related state of the art and the research gap will be presented subsequently. Section 3 presents a proactive, event-driven approach to DCM and the underlying information model. The paper concludes with the description of the ongoing implementation in industry and an outlook on further research.

\section{THE AUTOMOTIVE DCM}

This subsection gives an overview of the current management process, the challenges and the state of the art in automotive DCM to deduce the research gap.

\subsection{Automotive DCM Processes}

Automotive DCM planning process at OEMs can be classified using the Supply Chain Planning Matrix (SCPM): the matrix allocates the planning tasks vertically by planning horizons and horizontally by responsibilities of the OEM departments involved (Dörmer 2013, Fleischmann et al. 2015, Rohde et al. 2000, Schuh and Stich 2012). The automotive planning cycle typically starts with cross-functional strategic network planning. This long-term view typically includes uncertainties (Volling 2009), as the risk of temporary discontinuities in the material supply or the production process tend to make over-deterministic planning unsuitable (Liebler 2013). To handle the increasing number of car models and variants, strategic 
decisions can only provide the basis for the subsequent more detailed planning tasks in the mid-term horizon. The target of mid-term production planning is the optimisation of personnel and plant capacities. The primary customer demand for the next 12 to 24 months is forecasted in terms of volumes and customer selectable options (in the form of so-called option quotas). The later customer demand depends on the specific configuration of ordered cars. This aggregation reduces the existing complexity (Dörmer 2013, Volling 2009) and results from the possible forecast quality in the mid-term horizon (Dörmer 2013, Volling 2009). Changes in planned demand are triggered by general trends (e.g. urbanisation), scandals or political decisions (e.g. "diesel gate").

Subsequently, DCM processes ensure the availability of materials and resources for the mid-term production plan, even if specific material requirements are difficult to be determined from the aggregated planning volumes (Pawlikowski et al. 2017). If necessary, DCM proposes and initiates capacity adjustments to minimise costs for production, warehousing and human resources (Stadtler 2004). Like this, DCM acts as an essential interface between market demand, production and supply chain capacities (Arnold et al. 2008, Krog et al. 2002). Demand and capacity asynchronies are identified, and appropriate countermeasures are implemented in a reasonable time frame (Pawlikowski et al. 2017).

Then, internal negotiations are usually held in monthly sales meetings to adopt the production program to still necessary changes (Herold 2012). The aggregated procurement plan, production and transport capacities are derived from the identified production demand (Rohde et al. 2000). The result is a plant-dependent production schedule for volumes of defined product groups for each production week in the planning horizon (Dörmer 2013). Economic aspects should be taken into account in these processes (Barthel 2006), but feedback on the economic viability of capacity adjustments is not considered in the mid-term planning (Dörmer 2013).

In contrast, the later following short-term production planning uses customer orders. This deterministic primary demand can be used for the first time for a detailed demand calculation (Liebler 2013).

\subsection{Challenges of the Automotive DCM}

When central processes, structures and resources are fragmented and geared towards decentralisation, agility and speed (Gehrke 2017, Hompel and Henke 2014), production planning needs to become more flexible, too. For example, the current DCM process is no longer able to cope with the large number of planning impulses and the complexity of demand and capacity information. There is a need for a proactive and event-oriented evaluation of automotive production programs which shall be detailed in the following.

A highly complex set of technical rules describes the compatibility of car models and their potential options. Most of these options can be selected by the customer. Others are driven by marketing considerations, legal and political country-specific requirements and internal restrictions. The technical rules can prohibit or force options for certain models (e.g. no sports seats for a basic model). Because of dependencies among the options, the smallest change in the planned production program may affect greatly the part requirements and associated capacity utilisation of suppliers and other resources.

Moreover, after 125 years, car and drive concepts are fundamentally changing (Kampker et al. 2013). Alternative powertrain technologies are designed to reduce emissions. Electric mobility leads to changes in car architecture and product structure. Additional car variants are introduced within the short to mid-term period to react to changing market demand. At the same time, cars are increasingly connective and become more and more digitised by assistance systems (Gärtner and Heinrich 2018). Especially, the integration of intelligent assistance systems leads to a radical increase in the complexity of parts and car variants (Kampker et al. 2016, Krumm et al. 2014), resulting in a new complexity in the automotive DCM process.

Automotive product life cycles (PLC) amount to about seven years. Assuming a development time of three years, technologies used at the end of the PLC are ten years old (Kampker et al. 2017). Considering the rapid technological development of electronic components, PLCs in the automotive industry are far too long and will have to become shorter (Bundesregierung 2018). The developed markets are increasingly demanding customised products and solutions (Ehrenmann 2015) that adapt to new technological developments during the automobile PLCs. Today, OEMs are incentivised to upgrade electronic functions, components, parts or include numerous new parts within the PLC. In some cases, relationships with new supply chain partners arise (e.g. Apple or Google). On the one hand, the car is continually being redefined as a product, and the entire value chain must continually adapt to these changes (Kampker et al. 2013). On the other hand, it results in greater market dynamism and less predictable customer requirements in the mid-term. A significant flexibilisation of the entire value-added network is required to cope with these challenges.

The processing times for feedback on a production plan or a change within are currently in the range of several weeks. The current DCM process is only slightly automated today and characterised by many participants, iterative planning rounds and data distributed across many systems (MS Excel, SQL-DBs, flat files, etc.). The result is an increasing overload of the responsible human planners, an increasing frequency of bottlenecks as well as the associated costs. The example of a BMW bottleneck in 2017 illustrates how great the threat of a loss in quality and the associated loss of image is (Tagesschau 2017). In sum, the current DCM process is too static, too poorly digitalised and too slow for future automobile production. A more proactive, flexible and fast DCM process and a suitable DCM IT support are necessary. 
A suitable degree of automation combined with the support of intelligent planning procedures allows the human planner to plan quickly and validly in an environment of high uncertainty. Today, as a result of the long planning cycles, there is no iterative feedback loop installed between the production plan based on the sales forecast and the production program planning in the midterm. A real-time capacity check of planned production programs (like a pre-audit) will improve the quality of mid-term production planning by proactively identification of critical capacities.

An integration of continuous iterative feedback loops may increase the economic outcome of the production program when bottlenecks can be identified and avoided proactively. When determining costs for the capacity adjustment, it must be ensured that only the relevant costs are taken into account (Gottschalk 2005) which result from the comparison of planning scenarios (Ewert and Wagenhofer 2008). Costs of capacity adjustments include costs directly related to the provision and use of capacity flexibility (Gottschalk 2005). Additionally, opportunity costs must be considered (Kilger et al. 2012), as a possible profit could probably have been achieved if the capital employed for the measures had been used for a purpose other than that (Gottschalk 2005). An example is the lost contribution margin of car options of which the share decreases as a result of a supply bottleneck (Maiworm 2014). For decision support in medium and short-term sales planning, price limits (Kilger et al. 2012) can be applied for the acceptance of additional orders.

But DCM processes can only be accelerated if the relevant information is fully available in real-time. A prerequisite is the consistency and transparency of all DCM-relevant information.

\subsection{State of the Art of the Automotive DCM}

A review of relevant literature regarding automotive production program evaluation in the mid-term horizon has been conducted. The aim was to deduct the research gap clearly and understandably using a structured method by Webster and Watson (2002). The research has been based on the keywords "production planning", "capacity planning", "planning systems", "optimisation", "flexibility", "supply chain management", "the automotive industry" and "production and logistics". A total of 43 relevant publications have been identified. The concepts have been allocated to the planning concepts of the SCPM and been classified into the different horizons. Figure 1 shows the resulting classification of concepts.

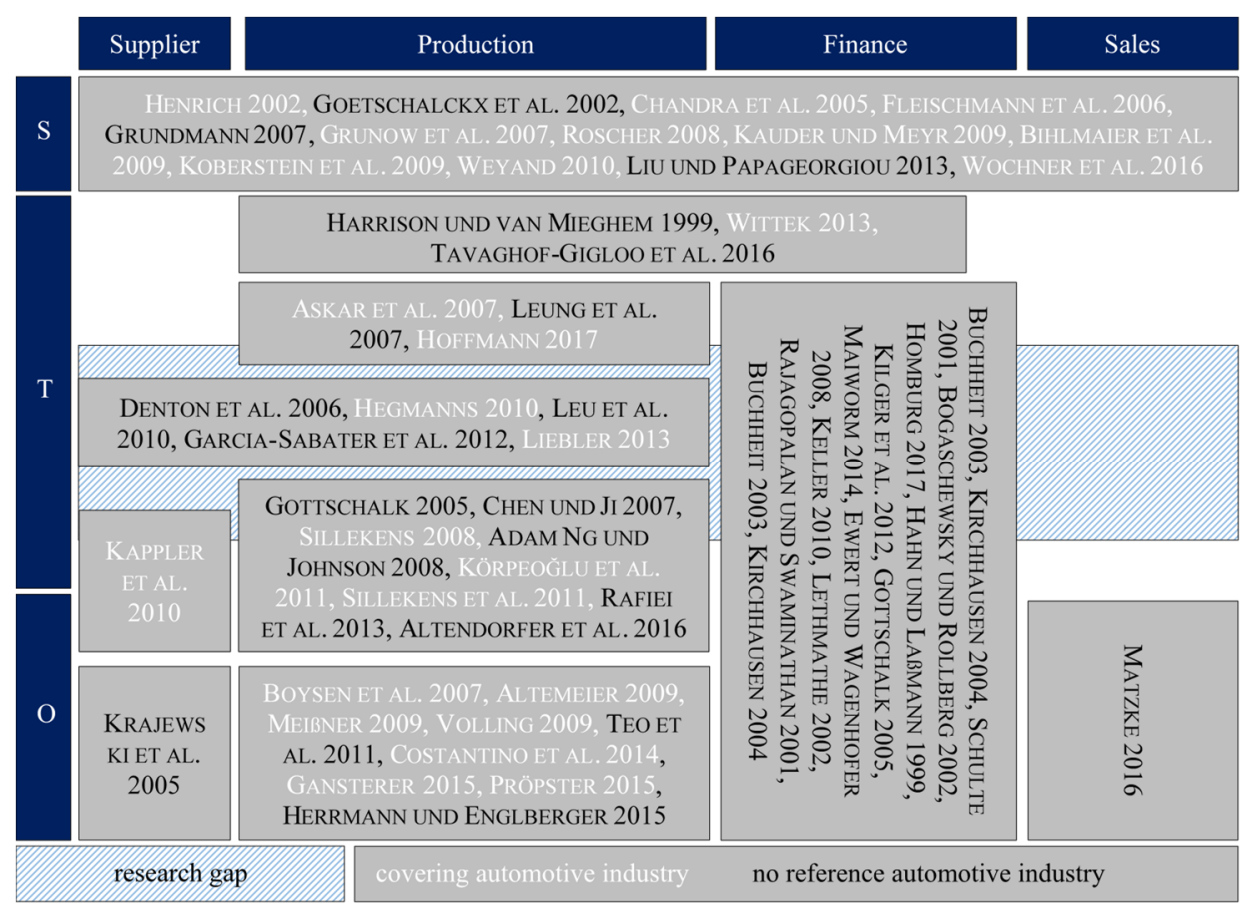

Figure 1: Research gap from the DCM in the mid-term horizon

13 of the 43 authors have been assigned to the strategic horizon, where distributive and capacitive factors of the cross-functional strategic network planning and product allocation are focused. The authors Grunow et al. (2007), Bihlmaier et al. (2009), Koberstein et al. (2009), Liu and Papageorgiou (2013) and Wochner et al. (2016) investigate the collaboration of distribution and production. Goetschalckx et al. (2002), Fleischmann et al. (2006) and Kauder (2008) examine a more holistic perspective and integrate all business areas except sales.
Henrich (2002) presents an automotive model for strategic planning for an entire supply chain. The production in the strategic horizon is the focus of the publications of Chandra et al. (2005), Grundmann (2007), Roscher (2008) and Weyand (2010). The authors in the mid-term horizon mainly focus on the OEM production. Only Kappler et al. (2010) work on suppliers and sales by presenting a robust calculation method for determining part requirements using ranges (Kappler et al. 2010). Denton et al. (2006), Leung et al. (2007), Leu 
et al. (2010), Körpeoğlu et al. (2011) and Rafiei et al. (2013) analyse the make-to-stock production. The authors Gottschalk (2005), Chen and Ji (2007), Adam Ng and Johnson (2008), Altendorfer et al. (2016) focus the tactical production planning but lack the specifics of the automotive industry. The authors Hegmanns (2010), Garcia-Sabater et al. (2011) and Liebler (2013) provide a holistic view on the mid-term horizon and, in addition, consider production, distribution and suppliers. Askar et al. (2007), Sillekens (2008), Sillekens et al. (2011), Hoffmann (2017) and Tavaghof-Gigloo et al. (2016) focus on the capacities of a production line.

Eleven authors have been assigned to the operative horizon. They focus on the production area of the company and deal with ascertained customer orders and not with demand forecasts or plans. Only Gansterer (2015) and Herrmann and Engelberger (2015) do not rely on orders but examine the transition from tactical to operational horizons. The authors Boysen et al. (2007), Altemeier (2009), Costantino et al. (2014), Pröpster (2015) and Matzke (2016) deal with the capacities of assembly teams. Krajewski et al. (2005), Volling (2009), Meißner (2009) and Teo et al. (2011) evaluate capacity adjustments.

Literature shows that it is not possible to deterministically validate demand plans within the midterm production planning since the secondary demand can only be determined precisely with specified customer orders. However, for reasons of economy, sales and midterm production planning are being carried out with a high degree of aggregation. Based on the literature review, there is a need for a new procedural concept which supports the event-oriented review of the production program. The literature review revealed no such concepts. Against the background of increasing market dynamics and globally linked supply networks, it is necessary to present a more integrated and dynamic concept for DCM. Therefore, an integrated, efficient information model is needed. Thus, the following section analyses the state of the art of automotive information models.

\subsection{State of the Art of Automotive Information Models}

Today, relevant data of automotive logistics is typically kept in several systems using relational data structures. However, a transparent and efficient information model is the key for DCM processes to assess the availability of automotive components. This information model has to depict all dependencies between parts, components and car features in a structured way (Fruhner et al. 2018). An elemental part of this information model is the product structure, which represents a structured form of the product and its components (Schuh and Riesener 2018). However, information on the dependence of planned model volumes, option quotas and material items is also needed as DCM processes synchronise market requirements with capacities and constraints of the supply chain and production system. A detailed analysis of information models in the automotive industry has been conducted in Fruhner et al. (2017). The analysed information models have been evaluated against these requirements which have been identified based on future challenges in the automotive industry: Integration of new dependencies, Integration of cross-functional Information, Modularity, Management of Comprehensive Data, and Transparency (Fruhner et al. 2017).

The literature review showed that approaches based on relational data structures quickly lead to poor transparency and redundancies as the data is distributed over several database systems (Bockholt 2012). A Design Structure Matrix (DSM) as proposed, for example, by Deng et al. (2012) or Kashkoush and ElMaraghy (2016) could support the representation of complex multidimensional and cross-functional automotive data. However, a DSM only allows to illustrate simple one-dimensional relationships. It is not possible to append additional cross-functional data, as its tabular structure easily becomes intransparent (Kissel 2014). Only similar relationships between two components can be mapped by semantic networks. No kind of hierarchy or at least an overall view can be integrated. Therefore, in complex data environments, the transparency is limited (Yang et al. 2012). Tree structures which have, for example, been presented by Kesper (2012) and Schuh $(1988,2018)$ do not offer modularity natively. However, an approach with evolving part/product families has been introduced by ElMaraghy et al. (2013). Moreover, it should be noted that tree structures can become very complex (Kesper 2012). With its hierarchical concept, the approach of Vegetti et al. (Vegetti et al. 2011) is a promising development. Two or more components can be joined together and form a more complex (sub-) assembly within the more general graph structure (Luo et al. 2016). Modularity is also supported in this way. Riggs and $\mathrm{Hu}$ (2013) introduce a precedence graph for disassembly, which is an especially enhanced graph structure.

Due to the findings of the literature review, a concept based on graph structures (including approaches of ontologies and semantic networks) is most suitable, as graph structures meet the requirements best.

\section{INTRODUCTION OF AN APPROACH FOR PROACTIVE AND EVENT-ORIENTED PRODUCTION EVALUATION}

A simplified but digitised, proactive DCM planning process is needed. Moreover, an efficient information model, which contains all relevant information, is required. Only the combination of both concepts might exploit the full potential. This section gives an overview of the concept SmartDCM and the new approach for an efficient information model.

\subsection{A Modular Process Kit for SmartDCM}

The developed qualitative research design addresses the empirical research gap in the automotive DCM and serves to derive the process modules needed for a proactive automotive DCM. It is based on data analysis 
of 48 guideline-based expert interviews at a plant of a German OEM with private and business customer segments which applies triangulation by combining two methods: the deductive category assignment is supplemented by inductive category formation. According to Mayring (2016), this triangulation improves the quality of research results compared to only one methodical approach. Transcribed text passages of the interviews that could not be assigned to a deductive category have been grouped into inductive categories according to predefined criteria. Three encoders have ensured the quality of the data evaluation in the deductive and inductive coding process. The need for a fast assessment of mid-term production programs to secure the supply of parts and incremental financial change has been validated. In short, it was revealed that an iterative feedback loop between the sales department and capacity providing departments dramatically increases the reaction time. To develop a holistic approach, the processes from literature have been enhanced by the identified requirements of entrepreneurial practice. It could be deduced, that the central vulnerability of today's DCM is reflected by the program approval that is not based on a detailed capacity check: the determination of requirements takes mostly place afterwards. Valuable empirical findings contribute to an application-oriented development of an event-oriented mid-term evaluation of the automotive production-planning program. Table 1 shows the developed modular process kit.

The process kit is divided into three thematic clusters: production program planning, capacitive evaluation and monetary evaluation.

The first thematic cluster production program planning contains nine process modules. The identification of the market requirements takes external parameters and trends into account. The internal requirement identification focuses on the existing restrictions within the OEM's internal production network. Subsequently, the primary requirements planning is carried out as proposed in literature. A comparison is made between the market requirements and the internal requirement identification to determine the production oriented sales planning. The process module for enriching the mid-term primary demand is an alternative to the forecast-based rough planning of resources. It provides the basis for the detailed capacity check of purchased and manufactured parts, containers and OEM internal resources for the midterm horizon.

The second thematic cluster capacitive evaluation contains eight process modules. The determination of the secondary demand is a relevant process step as proposed by literature. The production requirements planning contains the process steps procurement model assignment, inhouse production planning and external procurement planning. The detailed capacitive evaluation includes capacitive checking within the OEM's internal production network as well as balancing of capacities for purchased and manufactured parts and containers. The capacitive adjustment evaluation relies on relevant information such as marginal cost and capacities, lead times and throughput times for all known measures. If a capacity adjustment is not possible, customer demand may be controlled by demand management. To enable the iterative feedback loop, the capacitive feedback from these processes must be reintegrated into primary demand planning. Finally, the assessment of the overall security of supply summary of the production program takes all capacitive adjustments into account.

Table 1: Modular process kit for a proactive DCM

\begin{tabular}{|c|c|c|c|c|}
\hline category & \multicolumn{4}{|c|}{ required process modules } \\
\hline \multirow{9}{*}{$\begin{array}{l}\text { production } \\
\text { program } \\
\text { planning }\end{array}$} & PM1 & \multicolumn{3}{|c|}{ external requirement identification } \\
\hline & PM2 & \multicolumn{3}{|c|}{ internal requirement identification } \\
\hline & PM3 & \multicolumn{3}{|c|}{ primary requirements planning } \\
\hline & PM4 & \multicolumn{3}{|c|}{ analysis of existing restriction } \\
\hline & PM5 & \multicolumn{3}{|c|}{ determination of production oriented planning } \\
\hline & PM6 & \multicolumn{3}{|c|}{ event-driven production program changes } \\
\hline & PM7 & \multicolumn{3}{|c|}{ production program enrichment } \\
\hline & PM8 & \multicolumn{3}{|c|}{ production program summary } \\
\hline & PM9 & \multicolumn{3}{|c|}{ production program release } \\
\hline \multirow{18}{*}{$\begin{array}{l}\text { capacitive } \\
\text { evaluation }\end{array}$} & PM10 & \multicolumn{3}{|c|}{ secondary requirements planning } \\
\hline & PM11 & \multicolumn{3}{|c|}{ production requirements planning } \\
\hline & PM12 & \multicolumn{3}{|c|}{ interplant capacity evaluation } \\
\hline & \multirow{4}{*}{ PM13 } & \multirow{4}{*}{$\begin{array}{l}\text { detailed capacity } \\
\text { evaluation }\end{array}$} & $\mathrm{a}$ & internal production plant \\
\hline & & & $\mathrm{b}$ & purchased parts \\
\hline & & & $\mathrm{c}$ & manufactured parts \\
\hline & & & $\mathrm{d}$ & container \\
\hline & \multirow{4}{*}{ PM14 } & \multirow{4}{*}{$\begin{array}{l}\text { capacitive } \\
\text { adjustment } \\
\text { evaluation }\end{array}$} & $\mathrm{a}$ & internal production plant \\
\hline & & & $\mathrm{b}$ & purchased parts \\
\hline & & & $\mathrm{c}$ & manufactured parts \\
\hline & & & $\mathrm{d}$ & container \\
\hline & \multirow{2}{*}{ PM15 } & \multirow{2}{*}{$\begin{array}{l}\text { demand } \\
\text { management }\end{array}$} & $\mathrm{a}$ & internal production plant \\
\hline & & & $\mathrm{c}$ & manufactured parts \\
\hline & PM16 & \multicolumn{3}{|l|}{ capacitive feedback } \\
\hline & \multirow{4}{*}{ PM17 } & \multirow{4}{*}{$\begin{array}{l}\text { security of supply } \\
\text { summary }\end{array}$} & $\mathrm{a}$ & internal production plant \\
\hline & & & $\mathrm{b}$ & purchased parts \\
\hline & & & c & manufactured parts \\
\hline & & & $\mathrm{d}$ & container \\
\hline \multirow{2}{*}{$\begin{array}{l}\text { monetary } \\
\text { evaluation }\end{array}$} & PM18 & \multicolumn{3}{|c|}{ contribution marging determination } \\
\hline & PM19 & \multicolumn{3}{|c|}{ capacity adjustment costs determination } \\
\hline
\end{tabular}

The third thematic cluster monetary evaluation includes the financial evaluation and total feasibility check. For a financial comparison of a production program with its predecessor, the respective contribution margins are offset against each other after deduction of relevant costs incurred. To determine the contribution margin, the net cost of sales must be compared with the actual revenue of the planning period by summing up all product types (Hahn and Laßmann 1999, Kilger et al. 2012). Changes in the model mix, option mix or market distribution of the car volumes to be produced can have a positive or negative impact on the contribution margin of the production program.

Figure 2 visualises the proactive DCM process based on the modular process kit. The validation of the process kit is based on workshops to verify the research outcome with the interviewed experts. The workshops took place within each interviewed department at the OEM to ensure the correctness of the process modules within the process kit and to derive requirements for an efficient and user-friendly application development. Underlying requirements are, for example, appropriateness for the task, self-descriptiveness, identification and elimination of faulty customizability and controllability (Deutsches Institut für Normung 2008, Schneider 2008). The 
appropriateness for the task helps users to do their job effectively and efficiently. The self-descriptiveness ensures that each dialogue step is immediately understandable and that it is explained to the user on request. It is necessary to ensure the identification and elimination of faulty inputs with minimal correction effort as some data is entered by the users themselves (Krcmar 2015). The customizability allows adapting to user-specific needs, such as the choice of the preferred language or the reading direction from left to right. The controllability allows the user to initiate the dialogue process and to influence its direction and speed. To ensure the device-independent applicability of the SmartDCM, a web-based implementation has been recommended.

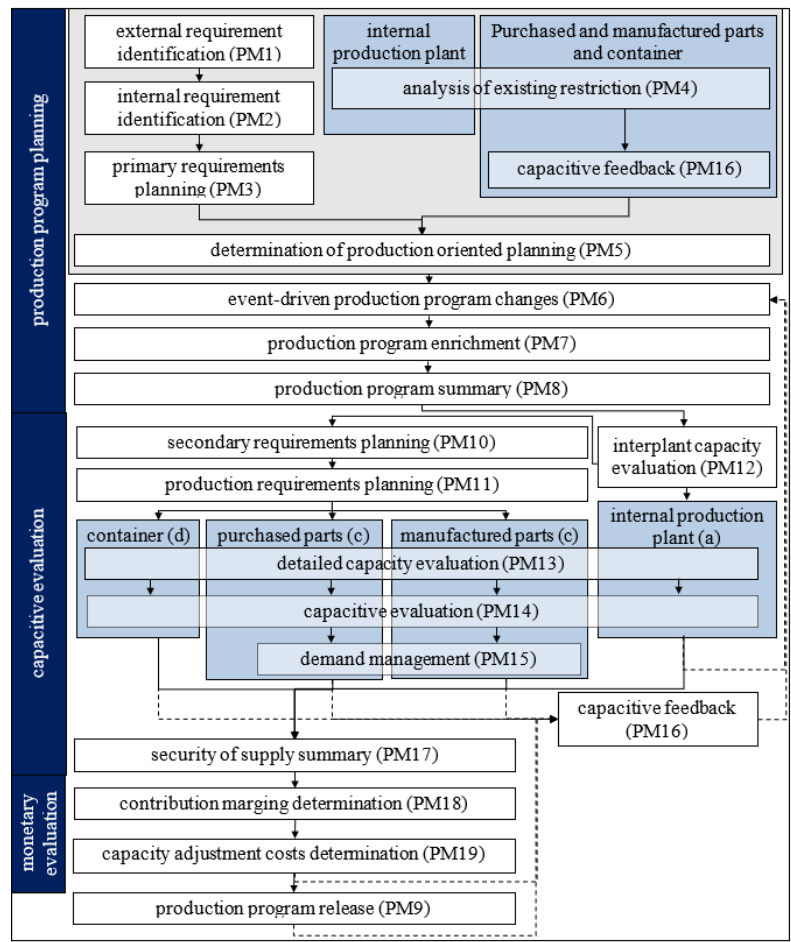

Figure 2: Process for a proactive DCM

\subsection{Information Model for Automotive DCM}

To implement the described new SmartDCM process, a new information model is needed, which holistically depicts the required information. The literature review revealed that DSMs, even if valuable in development, are not eligible for DCM and its complex cross-functional information. Especially semantic networks, tree structures and generalised graph structures have proven to be promising candidates for a new generation of information models. A graph structure has been chosen as the basis for SmartDCM, as it fulfils the requirements for a future-oriented information model (e.g. parallel component development).

As a next step, it was necessary to analyse what the information model used in the SmartDCM has to contain. For this purpose, data of two middle-class series of a German OEM have been analysed.

Each model of both car series can be sold in several markets, where each market has its own legal rules and customer preferences. Therefore, it is important to differentiate not only between models but also between model-market-combinations.

Each option is typically assigned to an option family (OFamily). This helps, for example, to avoid invalid configurations (e.g. two radios). In DCM processes, the planned volumes of car models and quotas of options are analysed to rule out asynchronicities. In case of a shift in demand, typically model volumes and option quotas are modified in synchronity. So, it is necessary to integrate the volume for model-market-combinations into the information model. All allowed options and the associated option families must also be mapped as well as the planned quota information. The technical and market-specific buildability of any car configuration is a key aspect for the validity of a production program. The highly complex set of technical rules (TECRule) must be integrated as well into the information model to account for this aspect. A car Type is divided into several Models. Furthermore, each Model is connected to several Markets. Moreover, within each Market, several Models can be sold.

For each Option, a Quota is necessary to anticipate customer orders. The Quota is based on the ratio of the occurrence of the Option in its Option-Family and is considered to be different for each Market. Therefore, each Option is connected to an Option-Family, a Quota and a Market. The same argumentation is valid for the relation between Models or Model-Market-combinations and Volumes. Furthermore, the Options and Markets are associated to the Technical Rules as those rules might block or force Options due to a specific combination of Options or Market-specific limitation.

The resulting data objects needed can be summarised as follows: Type, Model, Market, Volume, Option Family, Option, Quota and Technical Rules. Figure 3 shows the identified attributes transferred into a graph structure.

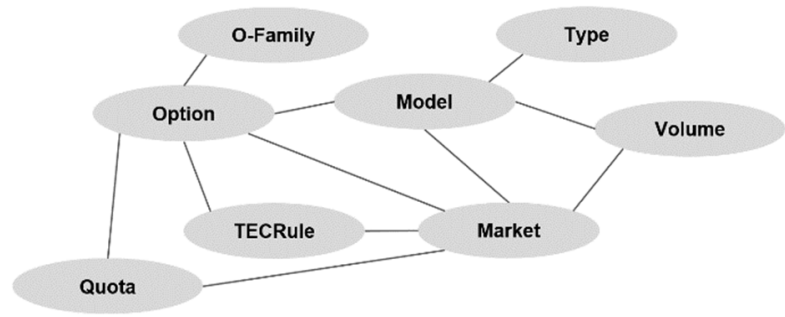

Figure 3: Efficient information model for SmartDCM

For the application, the introduced graph structure has been instantiated at a German OEM. Figure 4 shows the resulting class diagram in the Unified Modeling Language (UML). The model was supplemented within this step by the concept of variant cluster (VCluster). VClusters describe subsets of permitted variants with common characteristics. Each variant cluster inherits all the characteristics of its higher-level cluster. As a result, the model contains an efficient hierarchically linked cluster structure of variants. Thus, an effectively transparently representation of all the required information is given. First tests show that a production 
program evaluation can be performed efficiently using the developed information model.

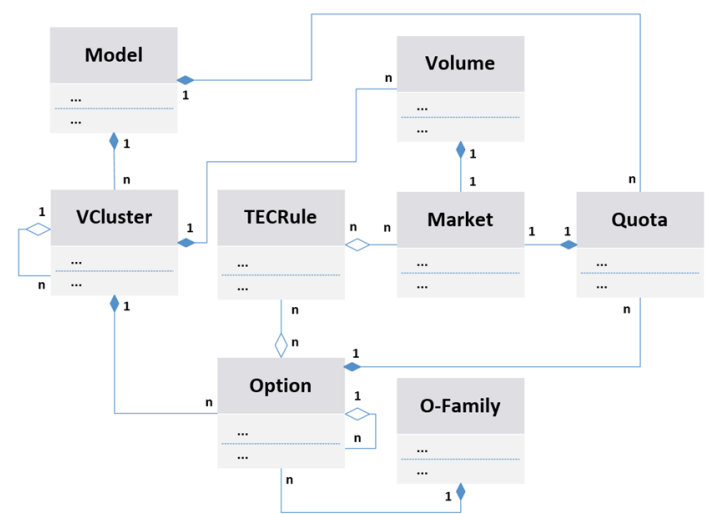

Figure 4: Instantiation of the developed graph structure

\section{SUMMARY AND OUTLOOK}

Digitisation in the automotive industry and the increasing number of variants are major challenges for future automotive DCM. Additionally, shorter life cycles and development cycles also increase the planning complexity. To overcome these challenges, this paper presents a modular process kit for a proactive automotive DCM which implicates a procedural change and an approach for efficient information model. The SmartDCM modular process kit provides an eventdriven capacitive evaluation of an automotive production program that contains country-specific car models and options. The capacitive feedback includes restrictions from manufactured and purchased parts, containers and internal production plants and is communicated to the sales department in iteration loops. To be able to manage the increasingly complex information, the attributes required in the SmartDCM have been identified first. Afterwards, the developed information model, including the required attributes, has been introduced and an instantiation for the prototypical implementation of SmartDCM at a German OEM has been performed. Currently, a software-suite is being developed, combining both the SmartDCM and the efficient information model. The implementation uses a serviceoriented architecture to react as flexible as possible to potential future changes in the DCM process or technological changes (e.g. new deep learning methods). In the next steps, the information model will be extended to include capacity information and especially the new and changed dependencies in automotive products which result from the increasing digitalisation of the car.

\section{REFERENCES}

Adam Ng, T. S. and Johnson, E. L., 2008. Production planning with flexible customization using a branchprice-cut method. IIE Transactions vol. 40, 11981210.

Altemeier, S., 2009. Kostenoptimale

Kapazitätsabstimmung in einer getakteten

Variantenfließlinie unter expliziter Berücksichtigung des Unterstützereinsatzes und unterschiedlicher
Planungszeiträume. Thesis $(\mathrm{PhD})$. Paderborn University.

Altendorfer, K., Felberbauer, T. and Jodlbauer, H., 2016. Effects of forecast errors on optimal utilisation in aggregate production planning with stochastic customer demand. International Journal of Production Research vol. 54, 3718-3735.

Arnold, D., Isermann, H., Kuhn, A., Tempelmeier, H. and Furmans, K., eds., 2008. Handbuch Logistik[Online], 3rd edn. Berlin: Springer. Available at: http://dx.doi.org/10.1007/978-3-54072929-7.

Askar, G., 2008. Optimierte Flexibilitätsnutzung in Automobilwerken. Thesis (PhD). Clausthal University of Technology.

Askar, G., Sillekens, T., Suhl, L. and Zimmermann, J., 2007. Flexibility Planning in Automotive Plants. In: Günther, H.-O., Mattfeld, D. C. and Suhl, L., eds. Management logistischer NetzwerkeEntscheidungsunterstützung, Informationssysteme und OR-Tools. Heidelberg: Physica-Verlag Heidelberg, 235-255.

Barthel, H., 2006. Modell zur Analyse und Gestaltung des Bestellverhaltens für die variantenreiche Serienproduktion. Thesis (PhD). Stuttgart. University of Stuttgart[Online]. Available at: http:// elib.uni-stuttgart.de/opus/volltexte/2007/2918/pdf/ Diss_Barthel_hs.pdf (Accessed 18 October 2017).

Bihlmaier, R., Koberstein, A. and Obst, R., 2009. Modeling and optimizing of strategic and tactical production planning in the automotive industry under uncertainty. OR Spectrum vol. 31, 311-336.

Bockholt, F., 2012. Operatives Störungsmanagement für globale Logistiknetzwerke: Ökonomie- und ökologieorientiertes Referenzmodell für den Einsatz in der Automobilindustrie. Thesis (PhD). TU Dortmund University.

Boysen, N., Fliedner, M. and Scholl, A., 2007. Produktionsplanung bei Variantenfließfertigung: Planungshierarchie und Elemente einer Hierarchischen Planung. Journal of Business Economics vol. 77, 759-793.

Chandra, C., Everson, M. and Grabis, J., 2005. Evaluation of enterprise-level benefits of manufacturing flexibility. Omega vol. 43, 17-31.

Chen, K. and Ji, P., 2007. A mixed integer programming model for advanced planning and scheduling (APS). European Journal of Operational Research vol. 181, 515-522.

Costantino, F., Toni, A. F. de, Di Gravio, G. and Nonino, F., 2014. Scheduling Mixed-Model Production on Multiple Assembly Lines with Shared Resources Using Genetic Algorithms: The Case Study of a Motorbike Company. Advances in Decision Sciences vol. 2014, 1-11.

Deng, X., Huet, G., Tan, S. and Fortin, C., 2012. Product decomposition using design structure matrix 
for intellectual property protection in supply chain outsourcing. Computers in Industry vol. 63, 632641.

Denton, B. T., Forrest, J. and Milne, R. J., 2006. IBM Solves a Mixed-Integer Program to Optimize Its Semiconductor Supply Chain. INFORMS Journal on Applied Analytics vol. 36, 383-342.

Deutsches Institut für Normung, 2008 9241-110:2006: Ergonomie der Mensch-System-Interaktion - Teil 110: Grundsätze der Dialoggestaltung (ISO 9241110:2006); Deutsche Fassung EN ISO 9241110:2006. Berlin: Beuth Verlag GmbH.

Dörmer, J., 2013. Produktionsprogrammplanung bei variantenreicher Fließproduktion: Untersucht am Beispiel der Automobilendmontage. Wiesbaden: Springer.

Ehrenmann, F., 2015. Kosten- und zeiteffizienter Wandel von Produktionssystemen: Ein Ansatz für ein ausgewogenes Change Management von Produktionsnetzwerken. Wiesbaden: Springer Gabler.

ElMaraghy, H., Schuh, G., ElMaraghy, W., Piller, F. T., Schönsleben, P., Tseng, M. and Bernard, A., 2013. Product variety management. CIRP Annals Manufacturing Technology vol. 62, 629-652.

Ewert, R. and Wagenhofer, A., 2008. Interne unternehmensrechnung. Berlin Heidelberg: Springer-Verlag.

Filla, P. and Klingebiel, K., 2014. Risk profiles for the pre-series logistics in automotive ramp-up processes. Procedia CIRP vol. 20, 44-49.

Fleischmann, B., Ferber, S. and Henrich, P., 2006. Strategic Planning of BMW's Global Production Network. INFORMS Journal on Applied Analytics vol. 36, 191-282.

Fleischmann, B., Meyr, H. and Wagner, M., 2015. Advanced Planning. In: Stadtler, H., Kilger, C. and Meyr, H., eds. Supply chain management and advanced planningConcepts, models, software, and case studies. 5th edn. Berlin Heidelberg: Springer, 71-95.

Fruhner, D., Klingebiel, K., Pawlikowski, K. and Toth, M., 2018. Impacts of the digitalised car on logistics. Proceedings of the 25th International Annual EurOMA Conference, June 24-26. Budapest, Hungary.

Fruhner, D., Pawlikowski, K., Klingebiel, K. and Toth, M., 2017. Efficient Product Representations for Automotive Logistics. Proceedings of the 29th European Modeling and Simulation Symposium (EMSS), 100-109, September 18 - 20. Barcelona, Spain.

Gansterer, M., 2015. Aggregate planning and forecasting in make-to-order production systems. International Journal of Production Economics vol. 170, 521-528.
Garcia-Sabater, J. P., Maheut, J. and Garcia-Sabater, J. J., 2011. A two-stage sequential planning scheme for integrated operations planning and scheduling system using MILP: The case of an engine assembler. Flexible Services and Manufacturing Journal vol. 24, 171-209.

Gärtner, C. and Heinrich, C., eds., 2018. Fallstudien zur Digitalen Transformation: Case Studies für die Lehre und praktische Anwendung[Online]. Wiesbaden: Gabler Verlag. Available at: http:// dx.doi.org/10.1007/978-3-658-18745-3.

Gehrke, L., 2017. Entwicklung eines Industrie-4.0Managementkonzepts als Beitrag zur digitalen Transformation der Logistik und Produktion. Dissertation. TU Dortmund.

Goetschalckx, M., Vidal, C. J. and Dogan, K., 2002. Modeling and design of global logistics systems: A review of integrated strategic and tactical models and design algorithms. European Journal of Operational Research vol. 143, 1-18.

Gottschalk, L. L., 2005. Flexibilitätsprofile: Analyse und Konfiguration von Strategien zur Kapazitätsanpassung in der industriellen Produktion. Zürich: ETH Zurich.

Grundmann, S., 2007. Planung flexibler Produktionskapazitäten im Spannungsfeld logistischer und monetärer Ziele. Dissertation. Gottfried Wilhelm Leibniz.

Grunow, M., Günther, H.-O., Burdenik, H. and Alting, L., 2007. Evolving Production Network Structures. CIRP Annals - Manufacturing Technology vol. 56, 427-430.

Hahn, D. and Laßmann, G., 1999. Produktionswirtschaft - Controlling industrieller Produktion: Band 1 \& Band 2: Grundlagen, Führung und Organisation, Produkte und Produktprogramm, Material und Dienstleistungen, Prozesse. Heidelberg: Physica-Verlag HD.

Hegmanns, T., 2010. Dezentrales Planungs- und Prozesskonzept für ein kollaboratives Bedarfs- und Kapazitätsmanagement in Produktionsnetzwerken. Zugl.: Dortmund, Techn. Univ., Diss.

Hegner, C., 2010. Modellbasierte Vernetzung strategischer und operativer Anlaufgrößen von interdependenten Fahrzeugprojekten. Dissertation. Technische Universität Chemnitz.

Henrich, P., 2002. Strategische Gestaltung von Produktionssystemen in der Automobilindustrie. Thesis (PhD). University of Augsburg.

Herold, L., 2012. Kundenorientierte Prozesssteuerung in der Automobilindustrie: Die Rolle von Logistik und Logistikcontrolling im Prozess ,,vom Kunden bis zum Kunden“[Online]. Wiesbaden: Deutscher Universitätsverlag. Available at: http://dx.doi.org/ 10.1007/978-3-322-85234-2.

Herrmann, F. and Englberger, J., 2015. Robuste Optimierung zur Produktionsprogrammplanung. In: 
Claus, T., Herrmann, F. and Manitz, M., eds. Produktionsplanung und steuerungForschungsansätze, Methoden und deren Anwendungen. Berlin: Springer Gabler, 25-45.

Hoffmann, U., 2017. Kennzahlenbasierte Entscheidungsunterstützung für die aggregierte Produktionsprogrammplanung. Dissertation. Technische Universität Chemnitz.

Hompel, M. ten and Henke, M., 2014. Logistik 4.0. In: Bauernhansl, T., Hompel, M. ten and Vogel-Heuser, B., eds. Industrie 4.0 in Produktion,

Automatisierung und LogistikAnwendung, Technologien, Migration. Wiesbaden: Springer Vieweg, 615-624.

Kampker, A., Deutskens, C., Heimes, H., Ordung, M. and Haunreiter, A., 2016. Using e-mobility as an enabler for a fast and lean product development to optimize the return of engineering with the example of lithium-ion battery. Procedia CIRP vol. 50, 166172.

Kampker, A., Gerdes, J. and Schuh, G., 2017. Think Big, Start Small: Streetscooter die e-mobile Erfolgsstory: Innovationsprozesse radikal effizienter. Berlin, Heidelberg: Springer.

Kampker, A., Vallée, D. and Schnettler, A., eds., 2013. Elektromobilität: Grundlagen einer Zukunftstechnologie: Springer Vieweg.

Kappler, J., Schütte, A., Jung, H., Arnhold, D. and Bracht, U., 2010. Robuste Primär-und Sekundärbedarfsplanung komplexer und variantenreicher Serienprodukte. Integrationsaspekte der Simulation: Technik, Organisation und Personal. Karlsruhe: KIT Scientific Publishing, 69-76.

Kashkoush, M. and ElMaraghy, H., 2016. Optimum Overall Product Modularity. Procedia CIRP vol. 44, 55-60.

Kauder, S., 2008. Strategische Planung internationaler Produktionsnetzwerke in der Automobilindustrie. Thesis (PhD). Vienna University Of Economics and Business.

Kesper, H., 2012. Gestaltung von Produktvariantenspektren mittels matrixbasierter Methoden. Thesis (PhD). Technical University of Munich.

Kilger, W., Pampel, J. and Vikas, K., 2012. Flexible Plankostenrechnung und Deckungsbeitragsrechnung. Wiesbaden: Gabler Verlag.

Kissel, M., 2014. Mustererkennung in komplexen Produktportfolios. Thesis (PhD). Technical University of Munich.

Klug, F., 2010. Logistikmanagement in der Automobilindustrie: Grundlagen der Logistik im Automobilbau. Berlin: Springer.

Koberstein, A., Bihlmaier, R., Obst, R. and Suhl, L., 2009. Ein Optimierungssystem für die strategische Produktions- und Kapazitätsplanung in der
Automobilindustrie. 9. Internationale Tagung Wirtschaftsinformatik, February 25 - 27. Vienna, Austria.

Körpeoğlu, E., Yaman, H. and Aktürk, M. S., 2011. A multi-stage stochastic programming approach in master production scheduling. European Journal of Operational Research vol. 213, 166-179.

Krajewski, L. J., Wei, J. C. and Tang, L.-L., 2005. Responding to schedule changes in build-to-order supply chains. Journal of Operations Management vol. 23, 452-469.

Krcmar, H., 2015. Informationsmanagement. Berlin, Heidelberg: Springer-Verlag Berlin Heidelberg.

Krog, E.-H., Richartz, G., Kanschat, R. and Hemken, M., 2002. Kooperatives Bedarfs- und Kapazitätsmanagement der Automobilhersteller und Systemlieferanten. Logistik Management, 45-51.

Krumm, S., Schopf, K. D. and Rennekamp, M., 2014. Komplexitätsmanagement in der Automobilindustrie - optimaler Fit von Vielfalt am Markt, Produktstruktur, Wertstrom und Ressourcen. In: Ebel, B. and Hofer, M. B., eds. Automotive ManagementStrategie und Marketing in der Automobilwirtschaft. 2nd edn. Berlin: Springer Gabler, 189-205.

Kuhn, A., Wiendahl, H.-P., Eversheim, W. and Schuh, G., 2002. Fast ramp up: schneller Produktionsanlauf von Serienprodukten: Ergebnisbericht der Untersuchung "fast ramp up". Verlag Praxiswissen, Dortmund vol. 6.

Leu, J.-D., Huang, L.-T. and Chen, C.-Y., eds., 2010. A MRP-II based planning method for the TFT-LCD manufacturing: IEEE.

Leung, S. C.H., Tsang, S. O.S., Ng, W. L. and Wu, Y., 2007. A robust optimization model for multi-site production planning problem in an uncertain environment. European Journal of Operational Research vol. 181, 224-238.

Liebler, K. M., 2013. Eine prozess- und IT-gestützte Methode für die Produktionsplanung in der Automobilindustrie. Thesis (PhD). TU Dortmund University.

Liu, S. and Papageorgiou, L. G., 2013. Multiobjective optimisation of production, distribution and capacity planning of global supply chains in the process industry. Omega vol. 41, 369-382.

Luo, Y., Peng, Q. and Gu, P., 2016. Integrated multilayer representation and ant colony search for product selective disassembly planning. Computers in Industry vol. 75, 13-26.

Maiworm, T., 2014. Lines, Pakete, Sonderausstattungen - Wege der Fahrzeugdifferenzierung und Margenverbesserung durch Upselling. In: Ebel, B. and B. Hofer, M., eds. Automotive Management. Berlin Heidelberg: Springer Gabler, 527-535. 
Matzke, A., 2016. Upgrade-Auktionen für die Nachfragesteuerung bei kundenindividueller Auftragsmontage: Mit Beispielen aus der Automobil- und Computerindustrie. Dissertation. Technische Universität Braunschweig.

Mayring, P., 2016. Einführung in die qualitative Sozialforschung: Eine Anleitung zu qualitativem Denken. weinheim, Basel: Beltz.

Meißner, S., 2009. Logistische Stabilität in der automobilen Variantenfließfertigung.

Meyr, H., 2004. Supply chain planning in the German automotive industry. OR Spectrum vol. 26, 447470.

Nagel, J., 2011. Risikoorientiertes Anlaufmanagement. Wiesbaden: Gabler Verlag.

Pawlikowski, K., Fruhner, D., Klingebiel, K., Toth, M. and Wagenitz, A., 2017. A Motivation and Evaluation of Hierarchical Data Structures for Application in Automotive Demand and Capacity Management. International Journal on Advances in Software, 155-166.

Pröpster, M. H., 2015. Methodik zur kurzfristigen Austaktung variantenreicher Montagelinien am Beispiel des Nutzfahrzeugbaus. Zugl.: Diss., München, Techn. Univ., 2015. Herbert Utz Verlag $\mathrm{GmbH}$.

Rafiei, H., Rabbani, M. and Alimardani, M., 2013. Novel bi-level hierarchical production planning in hybrid MTS/MTO production contexts. International Journal of Production Research vol. 51, 1331-1346.

Riggs, R. J. and Hu, S. J., 2013. Disassembly Liaison Graphs Inspired by Word Clouds. Procedia CIRP vol. 7, 521-526.

Rohde, J., Meyr, H. and Wagner, M., 2000. Die Supply Chain Planning Matrix. PPS-Management, 5 (1) vol. 5.

Romberg, A. and Haas, M., 2005. Der Anlaufmanager: Effizient arbeiten mit Führungssystem und Workflow - von der Produktionsidee bis zur Serie. Stuttgart: LOG X.

Roscher, J., 2008. Bewertung von Flexibilitätsstrategien für die Endmontage in der Automobilindustrie. Thesis (PhD). University of Stuttgart.

Schneider, W., 2008. Ergonomische Gestaltung von Benutzungsschnittstellen: Kommentar zur Grundsatznorm DIN EN ISO 9241-110. Berlin, Wien, Zürich: Beuth Verlag GmbH.

Schuh, G., 1988. Gestaltung und Bewertung von Produktvarianten: Ein Beitrag zur systematischen Planung von Serienprodukten. Thesis (PhD). RWTH Aachen University.

Schuh, G. and Riesener, M., 2018. Produktkomplexität managen: Strategien - Methoden - Tools[Online], 3rd edn. München: Hanser. Available at: http:// www.hanser-fachbuch.de/9783446452251.
Schuh, G. and Stich, V., eds., 2012. Produktionsplanung und -steuerung 1: Grundlagen der PPS, 4th edn. Berlin Heidelberg: Springer-Verlag.

Sillekens, T., 2008. Aggregierte Produktionsplanung in der Automobilindustrie unter besonderer Berücksichtigung von Personalflexibilität. Thesis (PhD). Paderborn University.

Sillekens, T., Koberstein, A. and Suhl, L., 2011. Aggregate production planning in the automotive industry with special consideration of workforce flexibility. International Journal of Production Research vol. 49, 5055-5078.

Stadtler, H., 2004. Supply chain management and advanced planning-basics, overview and challenges. European Journal of Operational Research vol. 163, 575-588.

Tagesschau, 2017. BMW wartet auf Bosch-Teile: Engpass in der Produktion[Online]. Available at: https://www.tagesschau.de/wirtschaft/boschbmw-produktionsstau-101.html (Accessed 3 May 2018).

Tavaghof-Gigloo, D., Minner, S. and Silbermayr, L., 2016. Mixed integer linear programming formulation for flexibility instruments in capacity planning problems. Computers \& Industrial Engineering vol. 97, 101-110.

Teo, C.-C., Bhatnagar, R. and Graves, S. C., 2011. Setting planned lead times for a make-to-order production system with master schedule smoothing. IIE Transactions vol. 43, 399-414.

Vegetti, M., Leone, H. and Henning, G., 2011. PRONTO: An ontology for comprehensive and consistent representation of product information. Engineering Applications of Artificial Intelligence vol. 24, 1305-1327.

Volling, T., 2009. Auftragsbezogene Planung bei variantenreicher Serienproduktion: Eine Untersuchung mit Fallstudien aus der Automobilindustrie. Wiesbaden: Gabler Verlag.

Webster, J. and Watson, R. T., 2002. Analyzing the past to prepare for the future: Writing a literature review. MIS quarterly, xiii-xxiii.

Weyand, L., 2010. Risikoreduzierte Endmontageplanung am Beispiel der Automobilindustrie. Saarbrücken.

Wochner, S., Grunow, M., Staeblein, T. and Stolletz, R., 2016. Planning for ramp-ups and new product introductions in the automotive industry: Extending sales and operations planning. International Journal of Production Economics vol. 182, 372-383.

Wong, W. K. O., 2017. Automotive Global Value Chain: The Rise of Mega Suppliers. London: Taylor and Francis.

Yang, Q., Pan, X., Wei, D. and Wu, K., 2012. Research on Individualized Product Requirement Expression Based on Semantic Network. Physics Procedia vol. 25, 1926-1933. 